\title{
REVISITING THE PAPER ON "PREDICTION OF HUMAN IMMUNODEFICIENCY VIRUS PROTEASE CLEAVAGE SITES IN PROTEINS"
}

\section{Kuo-Chen Chou}

Gordon Life Science Institute, Boston, Massachusetts 02478, United States of America; kcchou@gordonlifescience.org or kcchou38@gmail.com

\section{Running Title: HIV Protease Cleavage Sites}

About 25 years ago a very important paper on prediction of human immunodeficiency virus protease cleavage sites in proteins [1] was published.

Ever since then, a series of papers for predicting HIV protease cleavage sites in proteins have been stimulated (see, e.g., [2-36]). All these papers are very useful for developing new drugs against human immunodeficiency.

\section{REFERENCES}

[1] K.C. Chou, Review: Prediction of human immunodeficiency virus protease cleavage sites in proteins, Anal. Biochem., 233 (1996) 1-14.
[2] Y.D. Cai, K.C. Chou, Artificial neural network model for HIV protease cleavage sites in proteins, Advances in Engineering Software, 29 (1998) 119-128.

[3] Y.D. Cai, H. Yu, K.C. Chou, Using neural network for prediction of HIV protease cleavage sites in proteins, J. Protein Chem., 17 (1998) 607-615. [4] D.W. Cameron, A.J. Japour, Y. Xu, A. Hsu, J. Mellors, C. Farthing, C. Cohen, D. Poretz, M. Markowitz, S. Follansbee, J.B. Angel, D. McMahon, D. Ho, V. Devanarayan, R. Rode, M. Salgo, D.J. Kempf, R. Granneman, J.M. Leonard, E. Sun, Ritonavir and saquinavir combination therapy for the treatment of HIV infection, Aids, 13 (1999) 213-224.

[5] R.W. Doms, J.P. Moore, HIV-1 membrane fusion: targets of opportunity, J. Cell Biol., 151 (2000) F9-14. 
[6] R.W. Doms, Chemokine receptors and HIV entry, Aids, 15 Suppl 1 (2001) S34-35.

[7] D.M. Eckert, P.S. Kim, Design of potent inhibitors of HIV-1 entry from the gp41 $\mathrm{N}$-peptide region, Proc. Natl. Acad. Sci. U. S. A., 98 (2001) 11187-11192.

[8] M.J. Root, M.S. Kay, P.S. Kim, Protein design of an HIV-1 entry inhibitor, Science, 291 (2001) 884888.

[9] R.M. Zorzenon dos Santos, S. Coutinho, Dynamics of HIV infection: a cellular automata approach, Phys. Rev. Lett., 87 (2001) 168102.

[10] C.A. Bewley, J.M. Louis, R. Ghirlando, G.M. Clore, Design of a novel peptide inhibitor of HIV fusion that disrupts the internal trimeric coiled-coil of gp41, J. Biol. Chem., 277 (2002) 14238-14245.

[11] Y.D. Cai, X.J. Liu, X.B. Xu, K.C. Chou, Support Vector Machines for predicting HIV protease cleavage sites in protein, J. Comput. Chem., 23 (2002) 267-274.

[12] J. Fellay, C. Marzolini, E.R. Meaden, D.J. Back, T. Buclin, J.P. Chave, L.A. Decosterd, H. Furrer, M. Opravil, G. Pantaleo, D. Retelska, L. Ruiz, A.H. Schinkel, P. Vernazza, C.B. Eap, A. Telenti, Response to antiretroviral treatment in HIV-1infected individuals with allelic variants of the multidrug resistance transporter 1: a pharmacogenetics study, Lancet, 359 (2002) 30-36.

[13] T. Rognvaldsson, L. You, Why neural networks should not be used for HIV-1 protease cleavage site prediction, Bioinformatics, 20 (2004) 1702-1709.

[14] Z.R. Yang, A.R. Dalby, J. Qiu, Mining HIV protease cleavage data using genetic programming with a sum-product function, Bioinformatics, 20 (2004) 33983405.

[15] S. Sirois, T. Sing, K.C. Chou, Review: HIV-1 gp120 V3 loop for structure-based drug design, Current Protein and Peptide Science, 6 (2005) 413-422.

[16] S. Sirois, C.M. Tsoukas, K.C. Chou, D.Q. Wei, C. Boucher, G.E. Hatzakis, Selection of Molecular Descriptors with Artificial Intelligence for the Understanding of HIV-1 Protease Peptidomimetic Inhibitors-activity, Medicinal Chemistry, 1 (2005) 173-184.

[17] A. Gray, S.S. Karim, T.N. Gengiah, Ritonavir/saquinavir safety concerns curtail antiretroviral therapy options for tuberculosisHIV-co-infected patients in resource-constrained settings, AIDS, 20 (2006) 302-303.

[18] W.N. Gao, D.Q. Wei, Y. Li, H. Gao, W.R. Xu, A.X. Li, K.C. Chou, Agaritine and its derivatives are potential 2020 November Edition | www.jbino.com | Innovative Association 
inhibitors against HIV proteases, Medicinal Chemistry, 3 (2007) 221226.

[19] A. Kontijevskis, J.E. Wikberg, J. Komorowski, Computational proteomics analysis of HIV-1 protease interactome, Proteins, 68 (2007) 305-312.

[20] T. Rognvaldsson, L. You, D. Garwicz, Bioinformatic approaches for modeling the substrate specificity of HIV-1 protease: an overview, Expert Rev Mol Diagn, 7 (2007) 435-451.

[21] S. Sirois, M. Touaibia, K.C. Chou, R. Roy, Review: Glycosylation of HIV1 gp120 V3 loop: towards the rational design of a synthetic carbohydrate vaccine, Current Medicinal Chemistry, 14 (2007) 3232-3242.

[22] H. Kim, Y. Zhang, Y.S. Heo, H.B. Oh, S.S. Chen, Specificity rule discovery in HIV-1 protease cleavage site analysis, Comput Biol Chem, 32 (2008) 71-78.

[23] L. Nanni, A. Lumini, Using ensemble of classifiers for predicting HIV protease cleavage sites in proteins, Amino Acids, (2008) Accepted Mar-27-2008.

[24] H.B. Shen, K.C. Chou, HIVcleave: a web-server for predicting HIV protease cleavage sites in proteins, Anal. Biochem., 375 (2008) 388-390.
[25] A.M. Andrianov, Immunophilins and HIV-1 V3 loop for structurebased anti-AIDS drug design, J. Biomol. Struct. Dyn., 26 (2009) 445454.

[26] A.M. Andrianov, I.V. Anishchenko, Computational model of the HIV-1 subtype A V3 loop: study on the conformational mobility for structure-based antiAIDS drug design, J. Biomol. Struct. Dyn., 27 (2009) 179-193.

[27] L. Nanni, A. Lumini, A Further Step Toward an Optimal Ensemble of Classifiers for Peptide Classification, a Case Study: HIV Protease, Protein \& Peptide Letters, 16 (2009) 163-167.

[28] L. Nanni, A. Lumini, Using ensemble of classifiers for predicting HIV protease cleavage sites in proteins, Amino Acids, 36 (2009) 409-416.

[29] J.H. Wong, T.B. Ng, Y. Jiang, F. Liu, S.C. Sze, K.Y. Zhang, Purification and characterization of a Laccase with inhibitory activity toward HIV1 reverse transcriptase and tumor cells from an edible mushroom (Pleurotus cornucopiae), Protein \& Peptide Letters, 17 (2010) 10401047.

[30] T. Huang, Z. Xu, L. Chen, Y.D. Cai, $\mathrm{X}$. Kong, Computational Analysis of HIV-1 Resistance Based on Gene Expression Profiles and the Virus2020 November Edition | www.jbino.com | Innovative Association 
Host Interaction Network, PLoS ONE, 6 (2011) e17291.

[31] A. Maria Velasco, A. Becerra, R. Hernandez-Morales, L. Delaye, M.E. Jimenez-Corona, S. Ponce-de-Leon, A. Lazcano, Low complexity regions (LCRs) contribute to the hypervariability of the HIV-1 gp 120 protein, J. Theor. Biol., 338 (2013) 80-86.

[32] J. Dev, D. Park, Q. Fu, J. Chen, H.J. Ha, F. Ghantous, T. Herrmann, W. Chang, Z. Liu, G. Frey, M.S. Seaman, B. Chen, J.J. Chou, Structural Basis for Membrane Anchoring of HIV-1 Envelope Spike, Science 353 (2016) 172-175.

[33] B. Chen, J.J. Chou, Structure of the transmembrane domain of HIV-1 envelope glycoprotein, FEBS J, 284 (2017) 1171-1177.
[34] A. Piai, J. Dev, Q. Fu, J.J. Chou, Stability and Water Accessibility of the Trimeric Membrane Anchors of the HIV-1 Envelope Spikes, J. Am. Chem. Soc., 139 (2017) 1843218435.

[35] Q. Fu, M.M. Shaik, Y. Cai, F. Ghantous, A. Piai, H. Peng, S. RitsVolloch, Z. Liu, S.C. Harrison, M.S. Seaman, B. Chen, J.J. Chou, Structure of the membrane proximal external region of HIV-1 envelope glycoprotein, Proc. Natl. Acad. Sci. U. S. A., 115 (2018) E8892-E8899. [36] J. Mei, J. Zhao, Prediction of HIV1 and HIV-2 proteins by using Chou's pseudo amino acid compositions and different classifiers, Sci Rep, 8 (2018) 2359. 